\title{
Influenza "A" (A/Pr/6/32) Disease Treatment Response through Oral Administration of a Locally Sourced Lipid Solvent Fortified With Aloe Vera Gel into Guinea Fowls; a Review Paper from a Combined Class Semester Term Mph Project, Imo State University Owerri
} Ajobiewe $\mathrm{OJ}^{1,2,3^{*}}$, Ogundeji AA ${ }^{2}$, Umeji L ${ }^{2}$, Madukwe $\mathrm{J}^{2}$, Ajobiewe $\mathrm{HF}^{2,3}$, and Odunze ${ }^{2}$

${ }^{1}$ National Hospital Abuja, Plot 132 Garki Central District, Nigeria

${ }^{2}$ Imo state University Owerri Nigeria

${ }^{3}$ Bingham University Karu Nasarawa State of Nigeria

${ }^{3}$ National Veterinary Research Institute Vom, Plateau State of Nigeria

DOI: $10.36347 /$ sjams.2020.v08i05.038

| Received: 05.04.2020 | Accepted: 24.04.2020 | Published: 30.05 .2020

*Corresponding author: Ajobiewe OJ

Abstract

This work was aimed at testing the effectiveness of a locally sourced and fortified lipid solvent, on influenza A Disease virus in some infected poultry birds at the National Veterinary Research Institute, Vom (NVRI) Plateau State of Nigeria. The research was designed by randomly blocking (during lipid dilution process) thirty-five Guinea Fowls (35) in groups of seven (7) based on lipid dilutions viz; six (6) lipid dilution groups and the control group. Dilutions from $10^{-5}$ to $10^{-10}$ were used for the assay. $0.1 \mathrm{ml}$ of the respective dilutions was transferred to sterile Bijou bottles labelled with the corresponding lipid solvent dilution. Thereafter, equal volumes of $4 \mathrm{HA}$ unit concentration of neat suspension of influenza virus strain (A/PR/6/32) was added to each bottle for other critical stages of the neutralization/haemagglutination inhibition assays. It was observed that none of the Guinea fowls treated with equal mixture of the fortified lipid solvent and the influenza virus strain came down with the disease. While most of those treated with the influenza virus strain were significantly infected $(\mathrm{P}<0.05)$.

Keywords: Heamagglutination HA, influenza virus, Heamagglutination inhibition HAI, Lipid Solvent, NVRI, Neutralization Assay, Guinea Fowls.

Copyright @ 2020: This is an open-access article distributed under the terms of the Creative Commons Attribution license which permits unrestricted use, distribution, and reproduction in any medium for non-commercial use (NonCommercial, or CC-BY-NC) provided the original author and source are credited.

\section{STUDY BACKGROUND}

Influenza viruses belong to the family of Orthomyxoviridae. There are different genus under this family. These include Influenza virus A, Influenza virus $\mathrm{B}$, in fluenza virus $\mathrm{C}$, Influenza virus $\mathrm{D}$, and the unnamed Thogoto-like viruses. Virions are pleomorphic, often spherical, 80- $120 \mathrm{~mm}$ in diameter. Filamentous forms several micrometer in length also occur [1]. Virions consist of a lipid -containing envelope, with large peplomers $10^{-14} \mathrm{~mm}$ in length and 4-6 $\mathrm{mm}$ in diameter, representing trimetric hem agglutinin and tetrameric neuraminidase structures. Within the envelope there are helically symmetrical nucleocapsids of different size classes, 150-130 nm in length with a loop at one end. Virion $\mathrm{Mr}$ is $250 \times 10^{6}$; buoyant density is $1.19 \mathrm{~g} / \mathrm{cm}^{3}$ in sucrose. The genome consists of eight, seven, or six molecules of linear, negative sense, single stranded RNA, 10 to $13.6 \mathrm{~Kb}$ in overall size. Segment lengths range from 900 to 2350 nucleotides [2].
Influenza, commonly known as "the flu", is an infectious disease caused by an influenza virus [1]. Symptoms can be mild to severe[5]. The most common symptoms include: high fever, runny nose, sore throat, muscle and joint pain, headache, coughing, and feeling tired [1]. These symptoms typically begin two days after exposure to the virus and most last less than a week [1]. The cough, however, may last for more than two weeks [1]. In children, there may be diarrhea and vomiting, but these are not common in adults [6]. Diarrhea and vomiting occur more commonly in gastroenteritis, which is an unrelated disease and sometimes inaccurately referred to as "stomach flu" or the "24-hour flu[6]". Complications of influenza may include viral pneumonia, secondary bacterial pneumonia, sinus infections, and worsening of previous health problems such as asthma or heart failure [2,5]. 
Three of the four types of influenza viruses affect humans: Type A, Type B, and Type C [2,7]. Type $\mathrm{D}$ has not been known to infect humans, but is believed to have the potential to do so $[7,8]$. Usually, the virus is spread through the air from coughs or sneezes [1]. This is believed to occur mostly over relatively short distances [9]. It can also be spread by touching surfaces contaminated by the virus and then touching the eyes, nose, or mouth $[5,9,10]$. A person may be infectious to others both before and during the time they are showing symptoms [5]. The infection may be confirmed by testing the throat, sputum, or nose for the virus [2]. A number of rapid tests are available; however, people may still have the infection even if the results are negative [2]. A type of polymerase chain reaction that detects the virus's RNA is more accurate [2].

Frequent hand washing reduces the risk of viral spread, as does wearing a surgical mask[3]. Yearly vaccinations against influenza are recommended by the World Health Organization (WHO) for those at high risk[1], and by the Centers for Disease Control and Prevention (CDC) for those six months of age and older[11]. The vaccine is usually effective against three or four types of influenza [1]. It is usually well tolerated [1]. A vaccine made for one year may not be useful in the following year, since the virus evolves rapidly [1]. Antiviral medications such as the neuraminidase inhibitor oseltamivir, among others, have been used to treat influenza [1]. The benefit of antiviral medications in those who are otherwise healthy do not appear to be greater than their risks[12]. No benefit has been found in those with other health problems $[12,13]$.

Influenza spreads around the world in yearly outbreaks, resulting in about three to five million cases of severe illness and about 290,000 to 650,000 deaths $[1,4]$. About $20 \%$ of unvaccinated children and $10 \%$ of unvaccinated adults are infected each year [14]. In the northern and southern parts of the world, outbreaks occur mainly in the winter, while around the equator, outbreaks may occur at any time of the year [1]. Death occurs mostly in high risk groups - the young, the old, and those with other health problems [1]. Larger outbreaks known as pandemics are less frequent [2]. In the 20th century, three influenza pandemics occurred: Spanish influenza in 1918 (17-100 million deaths), Asian influenza in 1957 (two million deaths), and Hong Kong influenza in 1968 (one million deaths)[15-17]. The World Health Organization declared an outbreak of a new type of influenza $\mathrm{A} / \mathrm{H} 1 \mathrm{~N} 1$ to be a pandemic in June 2009[18]. Influenza may also affect other animals, including pigs, horses, and birds [19].

\section{HYPOTHESES}

\section{Null Hypothesis (Ho)}

Locally sourced lipid solvent has no healing effect on the INFLUENZA "A" (A/PR/6/32) Virus and as does not produce any significant healing effect.

\section{Alternate Hypothesis (Ha)}

Locally Sourced Lipid Solvent has a healing effect on the INFLUENZA "A" Virus disease and as such the healing effect is significant

METHOD: The students shared responsibility towards making the semester project for the award of an MPH in public health of Imo state University Owerri a huge success. They were randomly distributed into three planktons, viz; -

Plankton A, those to source for particular animal strain of the virus in which the final choice was the "Mouse adapted influenza "A" (A/PR/6/32) Virus";

Plankton B, those to look for the ethical clearance, as most of them were staff of research institutions/or had close affiliates in these research institutions engaged in vaccine production and monitoring in Nigeria:

Plankton $\mathrm{C}$, Those to prepare the reagents, get ready the needed materials for bird inoculation, Heamagglutination inhibition technique e.t.c. /result collation and report writing for evaluation and final assessment by me. When the stage was fully set, the following steps were followed:

Thirty five Guinea fouls (35) were obtained from the poultry unit of the National Veterinary Research Institute, Vom, and Jos. Plateau State, Nigeria. The fowls were groomed from egg to adulthood alive and fit for the study;

\section{GROUPING OF FOWLS}

The Fouls were grouped into seven (7) based on the fortified lipid dilution viz;

Group one (1): The control group

Group two (2): The group with lipid solvent dilution of $10^{-5}$

Group three (3): The group with lipid solvent dilution of $10^{-6}$

Group four (4): The group with lipid solvent dilution of $10^{-7}$

Group five (5): The group with lipid solvent dilution of $10^{-8}$

Group six (6): The group with lipid solvent dilution of $10^{-9}$

Group seven (7): The group with lipid solvent dilution of $10^{-10}$

Each group consists of five (5) fowls respectively. Each fowl was bled intravenously and tested for Heamagglutination reaction after the blood $(10 \%)$ collected in EDTA bottles. A total number of thirty-five fowls were used for this study. They were divided into seven (7) groups, i.e. ,, six (6) lipid solvent dilution groups and the control group ${ }^{\text {ee }}$. A ten-fold serial dilution of the lipid solvent was tested for neutralization i.e. a $10^{-1}$ to $10^{-10}$ using absolute alcohol as diluents. 
Dilutions from $10^{-5}$ to $10^{-10}$ were used for the assay. $0.1 \mathrm{ml}$ of the respective dilutions was transferred to sterile bijou bottles labelled with the corresponding lipid solvent dilution. Thereafter, equal volumes of 4HA unit concentration of neat suspension of INFLUENZA "A" (A/PR/6/32) Virus strain was added to each bottle. Bottles were gently agitated to mix their contents and kept on ice ready for inoculation. Fowl inoculation Thirty (30) were labelled for each lipid solvent dilution. $0.1 \mathrm{~mL}$ lipid/virus mixtures were inoculated into five (5) fowls bearing the respective lipid solvent dilutions. Five fowls were inoculated with $0.1 \mathrm{ml}$ each of the virus suspension to serve as virus control. Fowls were groomed for further one week.

\section{RESULTS}

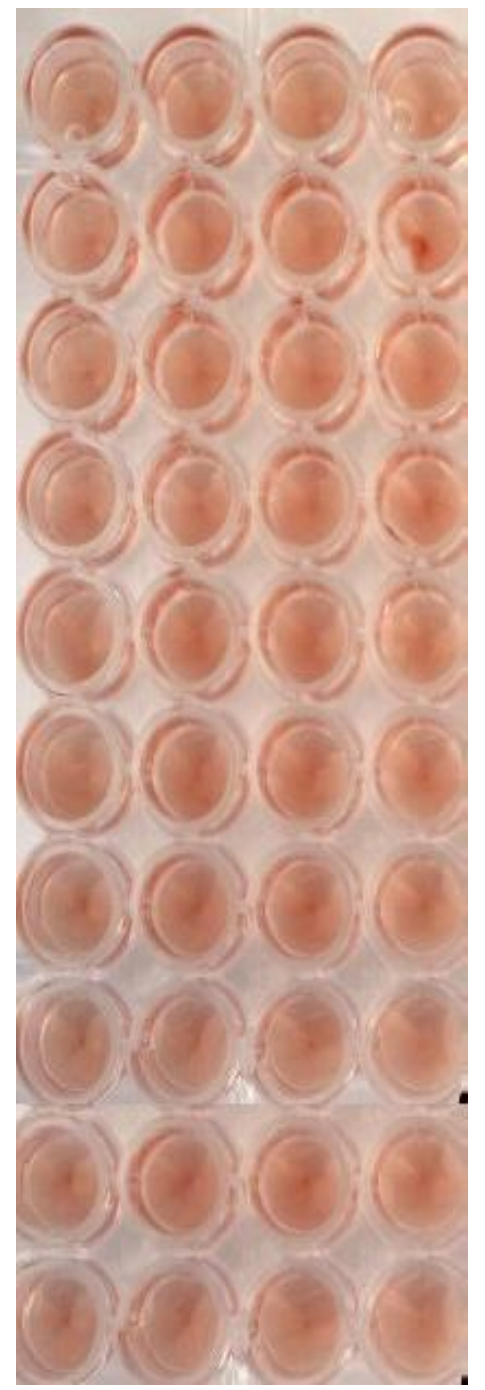

Fig-1: Showing positive Heamagglutination inhibition test in all the equally lipid solvent treated birds (Guinea fowls)

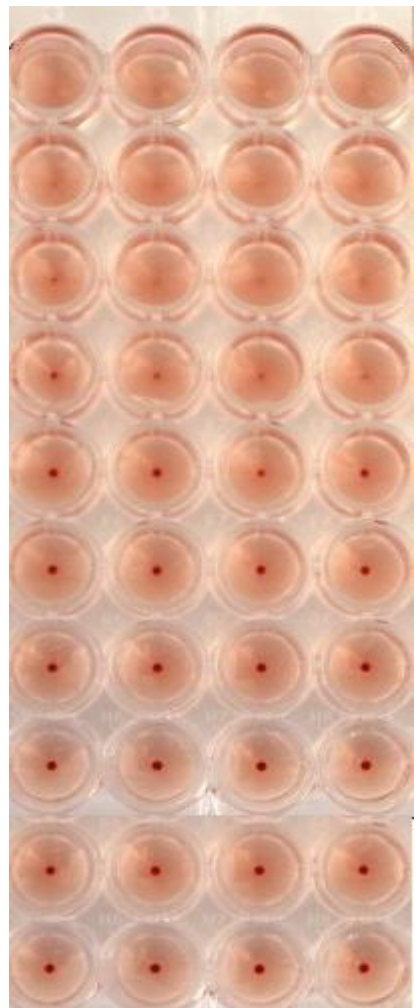

Fig-2: The index of 0.6 is applied to this dilution $=10^{-5-0.6}$ or 1 neutralized dose (influ.50) is $10^{-5.6}$ Therefore Neutralization titre $=$ $10^{-5.6 \text { Influ. } 50 / 0.1 \mathrm{ml}}$

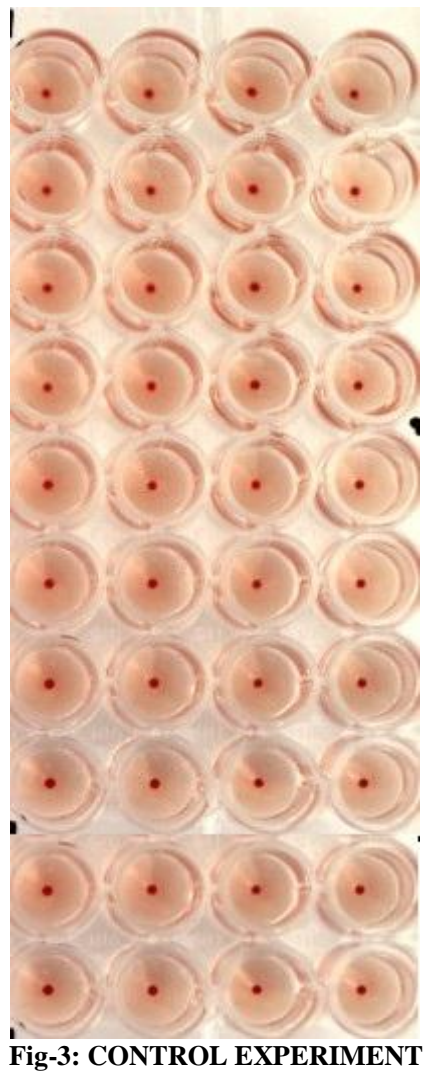




\section{Influenza treated bird's sera showing positive Heamagglutination reaction}

Each fowl was bled as stated earlier. All virus control birds tested positive for Heamagglutination reaction, indicating the presence of Influenza virus. Where the fluid did not agglutinate RBCs, it showed that the lipid has neutralized the virus.

Neutralization Index $=\{\%$ Neutralized at dilution immediately above 50\% - 50\% $/\{\%$ Neutralized at dilution immediately above 50\% - \% Neutralized at dilution immediately below $50 \%$ \}

\section{TABLE 1}

Dilution of $10^{-5} \%$ Neutralized above $50 \%=71.4 \%$ Dilution of $10^{-6} \%$ Neutralized below $50 \%=37.5 \%$ Neutralization index $=71.4 \%-50 \% / 71.4 \%-37.5 \%=$ $21.4 / 33.9=0.6$

The Neutralization index is then applied to the dilution that produced the percentage neutralized immediately above $50 \%$, which is $10^{-5}$

The index of 0.6 is applied to this dilution $=10^{-5}-0.6$ or 1 neutralized dose (influ.50) is $10^{-5.6}$ Therefore

Neutralization titre $=10^{-5.6 \text { Influ. } 50 / 0.1 \mathrm{ml}}$

\section{\{Stating how to calculate the Neutralization indices\}}

\section{DisCUSSION}

The study showed that lipid solvent had a neutralizing effect on the Influenza Virus. This supports the conclusions made that the locally sourced lipid solvent is naturally antimicrobial (killing harmful bacteria, yeast, fungus, viruses). The results obtained revealed that, the higher the dilutions, the greater the neutralizing effect of lipid solvent on influenza virus. All the experimental and control birds (Guinea fowls) were tested for neutralization activities by the Heamagglutination Inhibition test. From the table 1, results showed that Lipid solvent had $71.4 \%$ (above $50 \%$ ) neutralization effect on influenza virus at the dilution of $10^{-5}$ and $37.5 \%$ at dilution of $10^{-6}$. At dilution of $10^{-7}$, lipid solvent had $10 \%$ neutralization effect on the Influenza virus. Therefore we have no basis to reject the researcher's alternate hypothesis, Ha, which stated that lipid solvent has a neutralization effect on the Influenza virus, thus this was retained. While we have no enough evidence to retain the null hypothesis which stated that the lipid solvent had no neutralizing effect on the Influenza A Virus and as such we could not retain this hypothesis, hence it was rejected, or simply put, the Neutralizing dose was not significant". The dilution index of the Lipid solvent was 0.6 and when applied to the dilution that produced the percentage neutralized immediately above $50 \%$ which was $10^{-5}$, it resulted in a neutralized dose of (Influ. A 50) of $10^{-5.6}$. Therefore the Neutralization titre was $10^{-5.6 \text { Influ. } 50 / 0.1 \mathrm{ml}}$. The control birds were all intact and were all positive to Influ. A by the HA technique. This helped validate the experiment.

\section{REFFERENCE}

1. World Health Organization (WHO) (2018). "Influenza (Seasonal)"6 November 2018. Archived from the original on 30 November 2019. Retrieved 30 November 2019.

2. Longo DL. "Chapter 187: Influenza". Harrison's principles of internal medicine (18th ed.). New York: McGraw-Hill. 2012.

3. Jefferson T, Del Mar CB, Dooley L, Ferroni E, AlAnsary LA, Bawazeer GA. "Physical interventions to interrupt or reduce the spread of respiratory viruses" (PDF). Cochrane Database Syst Rev.2011; (7): CD006207.

4. World Health Organization (WHO) (Press release). 14 December 2017. Archived from the original on 18 April 2019. Retrieved 24 September 2019.

5. Centers for Disease Control and Prevention (CDC). 9 September 2014. Archived from the original on 2 December 2014. Retrieved 26 November 2014.

6. Duben-Engelkirk PG, Engelkirk J. Burton's microbiology for the health sciences (9th ed.). Philadelphia: Wolters Kluwer Health/Lippincott Williams \& Wilkins. 2011; 314. ISBN 978-160547-673-5.

7. Centers for Disease Control and Prevention (CDC). Types of Influenza Viruses Seasonal Influenza 27 September 2017. Retrieved 28 September 2018.

8. Su S, Fu X, Li G, Kerlin F, Veit M. "Novel Influenza D virus: Epidemiology, pathology, evolution and biological characteristics". Virulence. 2017; 8 (8): 1580-91.

9. Brankston G, Gitterman L, Hirji Z, Lemieux C, Gardam M. "Transmission of influenza A in human beings". Lancet Infect Dis. 2007; 7 (4): 257-65.

10. "Influenza in children". Paediatr Child Health. 2005; 10(8): 485-7.

11. Grohskopf LA, Alyanak E, Broder KR, Walter EB, Fry AM, Jernigan DB. Prevention and control of seasonal influenza with vaccines: recommendations of the Advisory Committee on Immunization Practices-United States, 2019-20 influenza season. MMWR Recommendations and reports. 2019 Aug 23;68(3):1.

12. Michiels B, Van Puyenbroeck K, Verhoeven V, Vermeire E, Coenen S. The value of neuraminidase inhibitors for the prevention and treatment of seasonal influenza: a systematic review of systematic reviews. PloS one. 2013;8(4).

13. Ebell MH, Call M, Shinholser J. Effectiveness of oseltamivir in adults: a meta-analysis of published and unpublished clinical trials. Family practice. 2013 Apr 1;30(2):125-33.

14. Somes MP, Turner RM, Dwyer LJ, Newall AT. Estimating the annual attack rate of seasonal influenza among unvaccinated individuals: A systematic review and meta-analysis. Vaccine. 2018 May 31;36(23):3199-207.

15. Spreeuwenberg $\mathrm{P}$, Kroneman M, Paget J. Reassessing the global mortality burden of the 
1918 influenza pandemic. American journal of epidemiology. 2018 Dec 1;187(12):2561-7.

16. World Health Organization. Ten things you need to know about pandemic influenza (update of 14 October 2005). Weekly Epidemiological Record= Relevé épidémiologique hebdomadaire. 2005;80(49-50):428-31.
17. Jilani TN, Jamil RT, Siddiqui AH. H1N1 Influenza (Swine Flu). InStatPearls [Internet] 2019 Jun 9. StatPearls Publishing.

18. Chan M. World now at the start of 2009 influenza pandemic. Palmer SR. Oxford textbook of zoonoses: biology, clinical practice, and public health control (2. ed.). Oxford u.a.: Oxford Univ. Press. 332. 